\title{
Making a little go a long way: A corpus-based analysis of a high- frequency word and some pedagogical implications for young Spanish learners
}

\author{
BELÉN LABRADOR DE LA CRUZ* \\ Universidad de León (Spain)
}

Received: 14/11/2018. Accepted: 05/04/2019.

\begin{abstract}
This study explores the different uses of the word little, its equivalents in Spanish and its teaching to young Spanish learners. First, it aims at analyzing the lexico-grammatical behavior of little in a corpus of children's short stories, where its prevailing use, preceding countable nouns, has been found to be much more frequent than in other domains and registers. A contrastive study follows, which examines how little has been translated in an English-Spanish parallel corpus; the results show that diminutives constitute an important equivalent. Finally, some didactic implications are proposed, with the application of corpus-based findings to the teaching of English to young Spanish learners from an approach that combines lexical syllabi and story-based methodologies.
\end{abstract}

KEYWORDS: English language teaching, corpus, little, young learners, lexical syllabus, stories.

\section{INTRODUCTION}

"One of the most valuable skills learners can acquire is that of making a little go a long way, of doing a lot with the limited language they have at their disposal" (Willis, 1990: 65). Making a little go a long way is what the present paper intends to promote, by literally taking the word little, and exploiting it to the full on the grounds of the lexical approach, by means of corpus linguistics and with a task-based teaching methodology in mind, addressed to Spanish young learners (henceforth YL) of English.

\footnotetext{
*Address for correspondence: Belén Labrador de la Cruz. Departamento de Filología Moderna. Universidad de León. Edificio Facultad de Filosofía y Letras. Campus de Vegazana, s/n, 24071 León;belen.labrador@unileon.es
} 
This word is apparently a 'little' word, in the sense of relatively unimportant, not serious, insignificant or trivial; however, there is much more to little than meets the eye. From a purely lexical perspective, it is a polysemous item with a variety of meanings and connotations: it has the meaning of small quantity, e.g. he ate little, size, e.g. a little car, extent, e.g. he has changed very little over the years or duration, e.g. in a little while; it is synonymous with younger (as in little brother or sister); it may be used in a positive way (e.g. a pretty little house in the country) but it may also be used in a negative way (e.g. one of those narrow-minded little racists) and it can be even used in a sort of humorous or attenuating way to refer to something that you really think is important, like a sort of litotes, e.g. We may have a little problem explaining that to our customers (Retrieved May 8, 2018 from http://www.macmillandictionary.com).

Grammatically speaking, it is a multifunctional item which is halfway between a functional word (whenever it is a determiner, e.g. little damage or a pronoun, e.g. give me just a little) and a lexical word (whenever it functions as an adjective, e.g. a little garden, or an adverb, e.g. move your arm a little). In terms of phraseology, it is a rich and dynamic word that takes part in a large number of collocations, fixed expressions and idioms, e.g. very little, a little bit, tiny little, little tiny, a tiny little bit, too little, so little, little by little, a little something, a little bird told me, the little woman, little frog in a big pond, etc.

The word little is also interesting from a phonological point of view, as it illustrates a case of size-related sound symbolism or phonoaesthesia. The size of the concepts expressed by some lexical items are thought to be cross-linguistically associated with phonetic factors like the height and backness of vowels, as some experiments have shown over decades (Sapir, 1929; Shinohara \& Kawahara, 2010; Ultan, 1978). Low or open vowels like /a:/, as in vast or large in English, are sound symbolic of large size, whereas a vowel like /I/, high and closed, usually evokes small things, as in little, tiny, wee, minute, itty-bitty, itsy-bitsy, thin, slim, skinny in English, chiquitito, chiquitín, diminuto, ligero in Spanish, petit in French, piccolo in Italian, liten in Norwegian and Swedish, pieni in Finish, lille in Danish. The sound /e/ has similar characteristics, e.g. in Spanish pequeño and /I/ can also be found in diminutive suffixes like -ito in Spanish and in English: -y: kitty, and -ling: duckling and in the prefix mini-, which represents small objects both in English and Spanish: minivan, minifalda [miniskirt]. Although there are exceptions and counterexamples in the lexicon for this association of sound and meaning; e.g., small has a low vowel, big has a high front vowel, and huge has a high vowel (Shinohara \& Kawahara, 2010: 407), in general, speakers of different languages seem to have "some non-arbitrary intuition about connections between sounds and meanings/images" (Shinohara \& Kawahara, 2010: 407) and in the case of the word little, this tendency seems to apply. Roig-Marín (2017: 33) advocates the benefit of learning sound symbolic words and claims that "learners should be encouraged to construct word knowledge by attending not only to the meaning but also to the form of the word". 
Apart from the intrinsic relevance of this lexico-grammatical item, two further reasons have triggered this study: the difficulty for Spanish YL of English to use this word properly and the general importance of the concepts of amount and size for children. As for the former, it is often the case that Spanish YL produce utterances like a little of sugar, instead of a little sugar (or some sugar), using little as a quantifier in places where a determiner should be used. This type of error can be considered either a transfer error, due to negative transfer or L1 interference, since the preposition is needed in Spanish (un poco de), or a developmental error, caused by overgeneralizing a rule, in this case, the pattern used with other similar words such as a lot of or a bit of. Other types of mistakes include comparative uses and attributive vs predicative position of little as an adjective, e.g. * a more little toy or * a littler toy rather than a smaller toy and ?the house is little rather than the house is small. The form-meaning mapping is complicated here because there is an intertwined network of English-Spanish contrastive relationships involving the word little which include both a case of divergence (from L1 pequeño to L2 little and small) and a case of convergence (from L1 pequeño and poco to L2 little).

This difficulty concerns Spanish-English transfer in particular; nevertheless, the importance and frequency of the word little in children's speech is likely to be universal. Little is likely to be found in child language, carer talk and motherese because it is used to address the children themselves, as they are little children, little boys and little girls, and also because of its positive semantic prosody- "little frequently has strong connotative meanings of cute and cuddly" (Stubbs, 1997: 112). This word tends to express affection, closeness, warmth and fondness, and it usually collocates with other positive words like nice, sweet, cute, pretty, poor, beautiful, cosy, darling, e.g. They live in a nice little cosy house; What a cute little doggy!, Poor little thing, you must be starving (examples from our corpus). Also, size and quantity are basic cognitive notions taught in the early years of education and little belongs to both conceptual fields.

The use of the word little is extralinguistically motivated since the children's world and the things in their world are often small in comparison with the grown-ups' world, e.g. they have small hands, so they wear small gloves, they grasp small toys and they sit on small chairs at small tables. In fact, the titles of a considerable number of children's stories illustrate this point: Little Red Riding Hood, The three little pigs, Little women, The little prince, The little mermaid, The brave little tailor, The little tin soldier, etc. In many of these cases, the traditional Spanish versions of these stories use the diminutive suffixes -ito or illo: Caperucita Roja, Los tres cerditos, Mujercitas, El principito, La sirenita, El sastrecillo valiente, El soldadito de plomo. On rare occasions the adjective pequeño is preferred: La pequeña cerillera (The little Match Girl); at least in the latter example there is an obvious phonetic reason for that, i.e. *cerillerita would sound too long and mouthful. Songs and nursery rhymes are another indication that little is recurrent in children-oriented texts, e.g. 
Twinkle twinkle little star, Little little spider, Five little ducks, Five little monkeys jumping on the bed, Hush little baby, Five little speckled frogs, I'm a little teapot, Little Bo Peep, Mary had a little lamb, Ten little Indians, This little piggy, Three little kittens, Two little dickie birds, What are little boys made of?, Where, O Where Has My Little Dog Gone?, etc. And the names of some children's television series constitute yet another piece of evidence, e.g. Little Einsteins, Big cook, little cook, Little people, Tayo the little bus, Little charmers, etc.

Finally, frequency lists are another proof of the importance and usefulness of teaching and learning this word. In the Word Frequency Data based on COCA, the Corpus of Contemporary American English (http://www.wordfrequency.info/free.asp?s=y), the word little as an adjective, ranks 257 in the list, as an adverb, 437 and as a determiner, 848, in the top 5,000 words of the 450 million word corpus. It is the $110^{\text {th }}$ most frequent word in Insightin online (http://www.insightin.com/esl/1000.php) and the $113^{\text {th }}$ most frequent word in ESL Kid Stuff (http://www.eslkidstuff.com/WordLists.htm). It is also among the 40 most basic words in Pre-K Dolch Sight Words (http://www.sightwords.com/sight-words/dolch/) and it ranks 106 in Fry's sight word list (http://www.k12reader.com/subject/vocabulary/frywords). The first sight words list was developed by Dolch in the 1930s-40s. He extracted the 315 most frequent words in children's books. The aim was to teach children these highlyoccurring words in order to facilitate the reading process, as they could focus their attention on the other words, after instantly recognizing the sight words. Fry developed a larger list of 1,000 words in the 1950s (and updated it in 1980), based on the most common words in reading materials used in Grades 3-9. The convenience of relying on Sight Word Lists for teaching purposes to assist in the reading learning process of native speakers of English is beyond the scope of this paper. However, the fact that the word little ranks high in these word lists supports the idea that it is a basic and frequent word in English, thus worth teaching to YL of English.

For all the above-mentioned reasons, little seems to be an interesting object of study, rich at all linguistic levels and relevant for learning, especially in the context of English Language Teaching (ELT) to YL. The present paper aims a) to explore this lexical item further through a corpus-based analysis, b) to gain insights into its relationship with its Spanish equivalents and c) to draw some inferences from the study and make some suggestions about the use of "corpus-informed" (McCarthy \& Handford, 2004: 18) lexical syllabi in combination with communicative methodologies.

\section{THEORETICAL BACKGROUND}

With the advent of corpus linguistics, lexical-based approaches appeared as alternatives to grammar-based approaches (Lewis, 1993; Nation, 2001; Nattinger \& DeCarrico, 1992; Sinclair \& Renouff, 1988; Willis, 1990), since corpora can provide information about the 
most frequent words in the most frequent patterns found in their most natural environment. Corpora allow for the observation of the actual usage of language by native speakers in a variety of domains. Therefore, language started to be thought as consisting of "grammaticalized lexis, not lexicalized grammar" (Lewis, 1993: 34) and the lexis to be taught was selected according to its frequency: "The commonest and most important, most basic meanings in English are those meanings expressed by the most frequent words in English" (Willis, 1990: 46) and to the learners' needs: "As we move down the frequency band we need to take more and more account of the needs of specific learners" (Willis, 1990: 47). These conceptions characterize the lexical approach (Sinclair, 1999).

This growing popularity of the lexical approach, of corpus-based research on vocabulary, chunks, lexical patterns and strings of words has largely influenced language teaching -as Flowerdew (2015: 112) states, "there is a tight bond between research and pedagogy in corpus work, with one informing the other". General, specialized and learner corpora have had an impact on pedagogy in two main ways: they are used sometimes in the form of direct applications (hands-on for learners and teachers), mainly affecting how to teach, and some other times in the form of indirect applications (hands-on for researchers and materials writers), which provide answers to questions of what to teach and when to teach it (Römer, 2010: 19). The present paper addresses the latter questions: the starting hypothesis is that the lexical item little constitutes a key element in ELT to YL; the corpus-based findings will reveal if this item is indeed a good candidate for inclusion in the syllabus (what to teach) at an early stage of learning (when to teach it). Searching for core vocabulary for inclusion in the syllabi is an important task for language teachers and course designers, "whose duty it is to choose, in a principled way, which words should be learned and when" (SiyanovaChanturia \& Webb, 2016: 231). Nordlund (2016: 54), for instance, has found that little, as well as big, good and old are high-frequency adjectives in two textbooks widely used in school years 4-6 in Sweden, namely Good Stuff and New Champion.

Accordingly, two important tenets of the lexical approach have been used as general guidelines: a) using an itemized syllabus, since the lexical approach "itemises language minutely, resting on a large body of research into natural language. On the basis of this research, it makes realistic and economical statements about what is to be learned" (Willis, 1990: viii), and b) applying content-based and communicative methods: "the methodology associated with the lexical syllabus does not depend on itemisation. It allows learners to experience language items in natural contexts and to learn from their experience" (Willis, 1990: viii). The lexical item little will be analyzed empirically with the use of corpora, but before that, and mainly drawing on Carter and McCarthy (2006: 102-104) and Biber et al., (1999: 508-512), Table 1 shows a summary of a theoretical revision of its multifaceted grammatical nature.

(C) Servicio de Publicaciones. Universidad de Murcia. All rights reserved. IJES, vol. 19(1), 2019, pp. 1-20 Print ISSN: 1578-7044; Online ISSN: 1989-6131 


\begin{tabular}{lll}
\hline \multicolumn{1}{c}{ Grammatical Function } & \multicolumn{1}{c}{ Meaning } & \multicolumn{1}{c}{ Example } \\
\hline DETERMINER (a little) & 'a small quantity of' & $\begin{array}{l}\text { Can you give me a little help } \\
\text { with the garden? }\end{array}$ \\
\hline DETERMINER (little) & $\begin{array}{l}\text { 'not as much as may be } \\
\text { expected or wished for' }\end{array}$ & $\begin{array}{l}\text { She has little real enthusiasm } \\
\text { for yoga; she only goes because } \\
\text { her friends go. }\end{array}$ \\
\hline QUANTIFIER (a little of) & 'a small part of something' & $\begin{array}{l}\text { Thanks, I'll have a little of the } \\
\text { soufflé, please. }\end{array}$ \\
\hline PRONOUN (a little) & 'a small quantity of something & $\begin{array}{l}\text { A: D'you want some more } \\
\text { soup? B: Give me just a little } .\end{array}$ \\
\hline PRONOUN (little) & 'not as much of something & $\begin{array}{l}\text { Little has been written on this } \\
\text { implicit as may be expected or }\end{array}$ \\
\hline ADVERB of degree & 'onished for' & $\begin{array}{l}\text { Try stretching your left leg a } \\
\text { little. }\end{array}$ \\
\hline $\begin{array}{l}\text { ADVERB in front position, } \\
\text { with subject-verb inversion }\end{array}$ & 'only to a small degree' & $\begin{array}{l}\text { Little did we think six months } \\
\text { ago we'd be going to another } \\
\text { funeral in the same family now. }\end{array}$ \\
\hline $\begin{array}{l}\text { ADVERB premodifying } \\
\text { adjectives }\end{array}$ & 'only to a small degree' & $\begin{array}{l}\text { They are both a little confused } \\
\text { and disoriented. }\end{array}$ \\
\hline $\begin{array}{l}\text { ADJECTIVE: Descriptor, } \\
\text { usually attributive and more } \\
\text { often found in spoken and } \\
\text { informal discourse }\end{array}$ & $\begin{array}{l}\text { 'small in size, short in length, } \\
\text { young in age, quick or brief in } \\
\text { duration and not serious or } \\
\text { important' }\end{array}$ & $\begin{array}{l}\text { a pretty little house in the } \\
\text { country }\end{array}$ \\
\hline
\end{tabular}

Table 1. Functions, meanings and examples of the word little.

The following section explains the corpus-based methodology used for the empirical research, which looks into the syntagmatic relationships of the word little.

\section{METHOD}

\subsection{The corpora}

The starting point of the research is the lexico-grammatical item little and two corpora have been used both as sources of data and as tools to carry out the study. CSS, a monolingual English-language corpus of Children's Short Stories, was built ad hoc and browsed with the Sketch Engine (Kilgarrif et al., 2014). It is composed of 454 short stories, extracted from children-oriented websites during the year 2016, and it amounts to over half a million words $(517,321)$. Some of the stories come from well-known folk tales or fairy tales originally written by Andersen, the brothers Grimm, Joseph Jacobs, Perrault, Beatrix Potter and Aesop; in these cases, apart from these versions, there may be others, which differ to a greater or lesser extent from the original stories; some others are new stories written by contemporary writers like Nathan Oser, Daniel Henshaw, David Lambert, Clare O'Dea, Deirdre and Jim McCarthy, etc. 
The parallel corpus used, P-ACTRES, is a general-domain corpus compiled by the ACTRES research group. The software used includes Perl programming language and shell scripts, Translation Corpus Aligner 2 (TCA2) (Hofland \& Reigem), Treetagger (Schmid, 1994), Corpus Workbench (Evert \& Hardie, 2011), HTML5 and JavaScript. P-ACTRES contains over 4 million words $(4,179,282)$, of which $2,523,458$ words correspond to the subcorpus of English source texts (STs) and Spanish target texts (TTs) and 1,655,824 words to the subcorpus of Spanish STs and English TTs. The latter subcorpus is smaller because it is still under construction. The texts included belong to different genres, grouped in 5 different subcorpora: fiction books, non-fiction books, newspaper articles, magazine articles and miscellanea. The first texts included in the first version of the corpus, P-ACTRES 1.0, which was unidirectional (from original English texts to their Spanish translations) date from 2000; gradually, since then, more texts have been incorporated and the new version, PACTRES 2.0, which is bidirectional (it also includes original Spanish texts and their translations into English) is more recent (https://actres.unileon.es for a demo and further information).

\subsection{The procedure}

There are several reasons why these two corpora have been used for this study. First, the complex semantic and grammatical differences between English and Spanish require a special pedagogical intervention, especially in a context where the word little is particularly common and useful - ELT to YL. A deep and thorough analysis of this case from different angles (general language, different registers, English and Spanish) can provide a solid support both to justify a prominent place of little in the curriculum of PreSchool and Primary Education and to identify likely difficulties in language usage caused by cross-linguistic differences.

Secondly, the inclusion of principles, resources and applications from different fields (corpus linguistics, translation studies, contrastive analysis and TEFL) in the present paper is based on the conviction that interdisciplinary research can lead to more productive results and wider perspectives. The attempts to link up the findings of some rather theoretical (though empirical) type of disciplines (contrastive and translation studies) with some more applied branches of linguistics (the teaching of a foreign language) can be challenging but worthwhile. Finally, mere pragmatic matters - simplicity, economy and the exploitation of suitable and ad hoc resources readily available have also contributed to using the two aforementioned corpora instead of adding for instance the use of a third corpus, like a large general English corpus.

The stages of the corpus-based research were as follows. First, the word little was searched for in both corpora to identify general language vs specialized language differences, and in the fictional and non-fictional subcorpora of original English texts in the parallel 
corpus to seek cross-register differences. Then, the concordance found in CSS was analyzed, which yielded a picture of the use of little in children's short stories. Next, the concordance of little retrieved from the non-fiction subcorpus was examined to observe the differences with respect to the uses in fictional corpus CSS. Finally, all the translations of the occurrences of little in the P-ACTRES fiction subcorpus were analyzed to look for the equivalents in Spanish. The analyses carried out in the different stages of the research process yielded outcomes associated with intralinguistic relationships: domain-specific or cross-register differences and interlinguistic relationships: contrastive differences between English and Spanish.

\section{RESULTS}

The first step of the analysis involved comparing the rates of occurrence of little in three different ways:

- First, a comparison of the frequency rates in a specialized corpus like CSS and a general-domain corpus like P-ACTRES. Table 2 shows that little occurs much more often in children's short stories $(3,794.54$ occurrences per million) than in a general language corpus ( 893.57 occurrences per million).

- Then follows a comparison of the figures in CSS and the non-fictional subcorpus of original English texts in P-ACTRES. As can be seen in Table 3, the frequency rates of little in a non-fictional corpus (P-ACTRES subcorpus of non-fiction books) are particularly low (584.13 occurrences per million).

- Finally, Table 4 shows a comparison between CSS and another fictional corpus (the fiction subcorpus in P-ACTRES), made up of novels, not specifically addressed to children. As can be seen, there is less difference between these two corpora $(3,794.54$ versus 1,710.12), as they are both fiction corpora, than between any of the others general-domain and non-fiction.

A statistical test was run, the two-proportion hypothesis test, which yielded the data displayed in the $\mathrm{z}$ and $\mathrm{p}$-value columns, and it shows that the differences are significant in the three cases because, in the three of them, the resulting $p$-value is less than $5 \%(p<0.05)$, and the corresponding confidence level is $95 \%$. Even more so, the three differences are especially significant, because the p-value is even lower: less than the significance level of $0.01 \%$ $(\mathrm{p}<0.0001)$ and the confidence level is $99.99 \%$.

This clearly demonstrates that little is a word that is used in children's short stories more often than in other text-types. 


\begin{tabular}{cccccc}
\hline Little & Hits & $\begin{array}{c}\text { Corpus size } \\
\left(\mathbf{N}^{\mathbf{0}} \text { of words) }\right.\end{array}$ & $\begin{array}{c}\text { Hits per } \\
\text { million words } \\
(\mathbf{P M W})\end{array}$ & $\mathbf{Z}$ & p-value \\
\hline CSS & 1,963 & 517,321 & $3,794.54$ & 41.56 & 0.000 \\
P-ACTRES & 1,075 & $1,203,038$ & 893.57 & & \\
\hline
\end{tabular}

Table 2. Comparison of the occurrences of little in CSS and P-ACTRES.

\begin{tabular}{cccccc}
\hline Little & Hits & $\begin{array}{c}\text { Corpus size } \\
\left(\mathbf{N}^{\mathbf{0}} \text { of words) }\right.\end{array}$ & $\begin{array}{c}\text { Hits per } \\
\text { million words } \\
(\text { PMW) }\end{array}$ & $\mathbf{Z}$ & p-value \\
\hline CSS & 1,963 & 517,321 & $3,794.54$ & 33.85 & 0.000 \\
Non- fiction & 281 & 481,056 & 584.13 & & \\
\hline
\end{tabular}

Table 3. Comparison of the occurrences of little in CSS and in P-ACTRES non-fiction subcorpus.

\begin{tabular}{cccccc}
\hline Little & Hits & $\begin{array}{c}\text { Corpus size } \\
\left(\mathbf{N}^{\mathbf{o}} \text { of words) }\right.\end{array}$ & $\begin{array}{c}\text { Hits per } \\
\text { million words } \\
(\text { PMW) }\end{array}$ & $\mathbf{Z}$ & p-value \\
\hline CSS & 1,963 & 517,321 & $3,794.54$ & 18.40 & 0.000 \\
\hline Fiction & 678 & 396,462 & $1,710.12$ & & \\
\hline
\end{tabular}

Table 4. Comparison of the occurrences of little in CSS and in P-ACTRES fiction subcorpus.

All the occurrences found in CSS were analyzed according to their co-text. Table 5 shows a classification of the uses of little, the number of hits for each use and their percentages.

\begin{tabular}{lcc}
\hline \multicolumn{1}{c}{ Uses of Little } & Hits & Percentages \\
\hline little + NP (count noun) & 1,529 & $77.89 \%$ \\
little + proper noun & 220 & $11.2 \%$ \\
V + (a) little (bit) & 51 & $2.6 \%$ \\
(a) little (bit) + AP & 38 & $1.94 \%$ \\
(a) little + NP (non-count noun) & 34 & $1.73 \%$ \\
little one/s & 27 & $1.38 \%$ \\
little as a pronoun & 18 & $0.92 \%$ \\
little as a predicative adj. & 16 & $0.82 \%$ \\
a little + PP/ AdvP & 15 & $0.76 \%$ \\
(a) little (bit) of & 7 & $0.36 \%$ \\
little by little & 6 & $0.31 \%$ \\
but little & 2 & $0.1 \%$ \\
& 1,963 & $100 \%$ \\
\hline
\end{tabular}

Table 5. Uses of little, number of hits and percentages in CSS.

As Table 5 shows, the most frequent use by far (accounting for three quarters of all the cases) is that of little followed by an NP (Noun Phrase) whose head is a countable noun which is usually preceded by determiners but hardly ever by premodifiers (example 1). In 
most cases, these premodifiers are colour adjectives (example 2), material adjectives (example 3), the adjective old (example 4) and other size adjectives (example 5). On some occasions, the noun has a diminutive suffix, emphasizing still more the meaning of small size expressed by little (example 6).

(1) 'Climb up! little boy,' said the Tree,..

(2) One day the little red hen found a seed.

(3) She dropped one of her little glass slippers.

(4) Once upon a time there lived in a little house under a hill a little old woman and her two children.

(5) and in came a little weeny dwarf no bigger than your hand.

(6) A mother duck and her little ducklings were on their way to a lake one day.

The most common noun collocates refer to people: child/ children, boy/s, girl/s, kid, man, woman, maid, maiden, fellow, prince, princess, shepherdess, piper, and their relationships: son, daughter, mother, sister, brother, friend/s; to fantastic characters: mermaid, gnome/s, fairy, creatures; to animals: animals, bird/s, dog, cat, duck, fish, frog, duckling, hummingbird, lamb, pig/s, mouse, mice, city mouse, country mouse, robin; to places: house, hut, cottage, garden, way, boat, room, hole; to objects: beds, doll, hat, pot; to parts of the body: face, finger, head and to sounds: noises, tap, voice. The word piece is usually followed by bread (a little piece of bread) and the word thing is usually part of the expression poor little thing referring to a person, with positive connotations. Another common collocation is a little while, as in example 7.

(7) After a little while, she felt afraid of one of the shadows in the bedroom.

Little preceding proper nouns ranks second in this list (example 8). Also cases like example 9 have been included in this category, where an NP becomes lexicalized as a proper noun.

(8) But Little Ania never really slept.

(9) Where are you going, Little Red Riding Hood?

As a modifier of a verb, little occurs in a good number of cases, both with the article $a$ implying a small but sufficient amount (example 10) and without it, emphasizing the opposite of much (example 11). It is not rare to find little as a fronted adverbial in declarative clauses with subject-verb inversion (example 12).

(10) Let us chat a little.

(11) If they loved Donald little before, they loved him less now.

(12) Little did they dream that a pretty young mermaid was down below.

๑) Servicio de Publicaciones. Universidad de Murcia. All rights reserved. IJES, vol. 19(1), 2019, pp. 1-20

Print ISSN: 1578-7044; Online ISSN: 1989-6131 
The following category includes the cases, like example 13, where little is a premodifier of an adjective, sometimes preceding bit, as in 14 .

(13) The old man seemed a little uneasy.

(14) He was also a little bit nervous..

Little followed by a non-count noun is the following category. In this case, the meaning expressed by little has more to do with amount than size (example 15). Collocates include both concrete non-count nouns: water, food, money, wealth, assistance, cost and abstract: music, trouble, hope, time.

(15) He would go into the forest and chop wood and sell it in exchange for a little rice.

Little also occurs in NPs with the proform one or ones as the head (examples 16 and 17).

(16) At first it was difficult to see the little one.

(17) The eldest sister asked, while the two little ones walked slowly round Tommy.

Three different uses of little come next in similar percentages: little or a little as a pronoun (examples 18 and 19), as a predicative adjective (example 20) and followed by a PP (Prepositional Phrase) or an AdvP (Adverbial Phrase) (examples 21 and 22).

(18) We got little, yet we went far.

(19) He took a little and put it in his mouth.

(20) I am the turtle whose life you saved when you found me, little and helpless, in your net.

(21) Still a little in front, Enid rode silently on, and Geraint followed.

(22) He made kind of a trumpeting/snorting sound that was a little too close to laughter for me.

Minor cases include the use of little as a quantifier, followed by a PP headed by of (example 23), the expression little by little (example 24) and the expression but little (example 25).

(23) Hansel reached up above, and broke off a little of the roof to try how it tasted.

(24) Little by little, object by object, the fairies brought colour to the scene.

(25) He would say but little. 
All these uses of little and their proportions are specific to children's short stories. If we compare these results with those found in a very different type of corpus, P-ACTRES non-fiction subcorpus, we can observe noticeable cross-register differences.

\begin{tabular}{lcc}
\hline \multicolumn{1}{c}{ Uses of Little } & Hits & Percentages \\
\hline (very)/ (a) little + NP (non-count noun) & 102 & $36.3 \%$ \\
little + NP (count noun) & 54 & $19.22 \%$ \\
V + (a) little (bit) & 40 & $14.23 \%$ \\
(a) little (bit) + AP & 23 & $8.19 \%$ \\
little as a pronoun & 22 & $7.83 \%$ \\
a little + PP/ AdvP & 10 & $3.56 \%$ \\
(a) little (bit) of & 10 & $3.56 \%$ \\
little more than & 7 & $2.49 \%$ \\
little or no + NP & 5 & $1.78 \%$ \\
little + proper noun & 3 & $1.07 \%$ \\
little as a predicative adj. & 2 & $0.71 \%$ \\
as little as & 2 & $0.71 \%$ \\
little but & 1 & $0.36 \%$ \\
TOTAL & 281 & $100 \%$ \\
\hline
\end{tabular}

Table 6. Uses of little, number of hits and percentages in P-ACTRES non-fiction subcorpus.

As can be seen in Table 6, the most common use of little is as a premodifier of noncount nouns (example 26), sometimes premodified by the intensifier very (example 27), as opposed to the preference for count nouns in CSS. Nonetheless, the use with count nouns, as in example 28 , ranks second.

(26) There is little doubt that the knowledge of Byzantine naval weakness must have contributed significantly to the crusaders' assessment of whether they could offer military support to Prince Alexius.

(27) Potassium and a very little sodium are literally good for your nerves.

(28) This allows the little bubbles of nitrogen to dissipate harmlessly.

The use of little as a modifier of verbs, as in example 29 , is also quite frequent. It occurs very often in the passive voice (example 30) and sometimes as a fronted adverbial in clauses with subject-verb inversion (example 31).

(29) The tourniquet was loosened just enough to allow the arteries to bleed a little.

(30) Yet this paradox of democratic legitimacy has a corollary which has been little noted.

(31) Little did I know that I would be the first to apply these mechanisms in the 1980s.

Next in the scale we find little as a modifier of adjectives (example 32) and as a pronoun (example 33). 
(32) I hope by now that you are at least a little bit skeptical of that approach.

(33) Only about 3 per cent of the world's phytoplankton - far too little, it would seem, to support a complex ecosystem.

Little preceding PPs and Advs (example 34) is not so common but occurs a few times, just the same as its use as a quantifier (example 35).

(34) Let's dig a little deeper into the secret of Gottman's success rate.

(35) Roper assemblages display little of the morphological variety that documents eukaryotic diversity in younger Proterozoic beds.

And finally, there is a number of minor uses: the expression little more than (example 36), little or no (example 37), little + proper noun (example 38), little as a predicative adjective (example 39), the emphatic expression as little as (example 40) and little but (example 41).

(36) (...) revolutions are little more than unusually good occasions for crime.

(37) In Poland untold numbers of suspects were arrested or killed on the basis of little or no evidence.

(38) So I put his father in the White House, thinking, how could little Georgie survive this?

(39) The growth was too little and too un-even in its impact to lift the entire population from extreme poverty.

(40) The disease cycle can be completed in as little as 60-72 hr under ideal conditions.

(41) A tomato, at 95 per cent, is little but water.

The use of little in NPs, preceding count, non-count and proper nouns is high in both fiction and non-fiction, but extremely more so in fiction: $90.83 \%$ in CSS and $56.59 \%$ in PACTRES non-fiction subcorpus. The use of little with count and proper nouns prevails in CSS whereas the non-fiction corpus tends to use little with non-count nouns.

The next stage of the analysis consisted of the observation of the translations into Spanish of little in the P-ACTRES fiction subcorpus. Little followed by a count noun accounts for over half the occurrences $-52.06 \%$, considerably higher than the proportion in the non-fictional subcorpus (19.22\%) and considerably lower than the proportion in the CSS $(76.52 \%)$.

Another noticeable difference between the P-ACTRES fiction subcorpus and CSS is the fact that there are more negative connotations of little in the former, e.g. You little fool!, His cheap little bitch-wife, some spiteful little penpusher, you nasty little liar, you little bastards, nasty little voice, nasty, pale-faced little thing.

These 353 lines of concordance of the P-ACTRES fiction subcorpus have been analyzed in terms of their translations into Spanish and the results are displayed in Figure 1. 


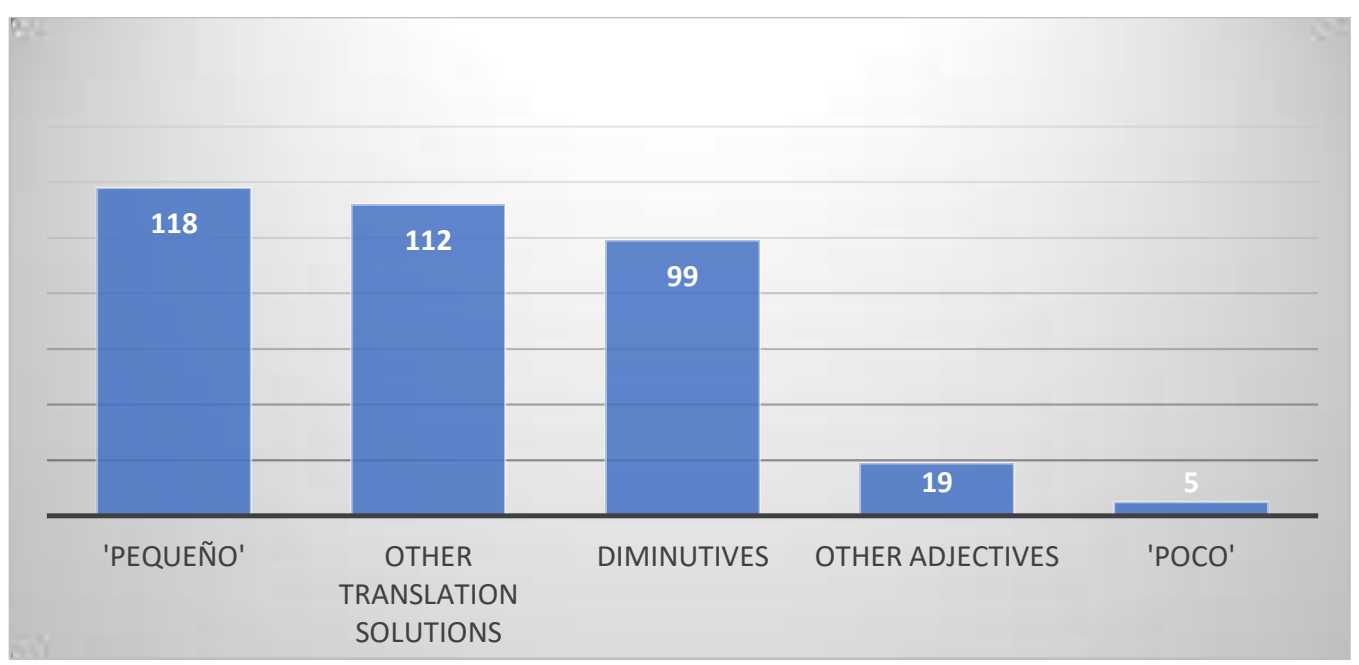

Figure 1. Translations of little into Spanish in P-ACTRES fiction subcorpus.

Figure 1 shows a predominance of the lexeme pequeño/a/os/as (118 occurrences), closely followed by other translation solutions (112 occurrences) that do not make use of an equivalent of little (there has been avoidance) for a number of good reasons: the meaning has been left implicit- the noun constitutes a lexicalized option (as in example 42), an idiom has been used (example 43), there has been transposition - "a shift of word class, i.e. verb for noun, noun for preposition" (Molina \& Hurtado, 2002: 499), as in example 44, modulation "a shift in point of view, focus or cognitive category in relation to the ST" (Molina \& Hurtado, 2002: 510), as in example 45, etc. Both transposition and modulation are sometimes alternatively considered together as the same category of translation solution: "perspective change" (Pym, 2016: 226).

(42) She touched her eye, her chest, then pointed at us -a thing she'd done since she was a little girl.-Se tocó el ojo, el pecho, y nos señaló; un gesto que había hecho desde que era niña.

(43) He stole little looks at her. La miró varias veces de reojo.

(44) I had a little bet with myself that your mouth would fall open at the sight of me. - $\underline{\text { Me }}$ había apostado conmigo mismo que te quedarías boquiabierta al verme.

(45) 'Here I come' he said and he drained the little bottle in one gulp. -Allá voy- dijo, y se bebió el contenido de un trago.

Almost as frequent as these two translation solutions is the use of diminutives (a total of 99 times): -ito/a/os/as occurs 71 times, -illo/a/os/as 19 times and then some minor diminutives like -ete, -elo/a, -ejo and-orrio occur 9 times. Instead of the adjective pequeño, a number of other adjectives have been used on some occasions, such as ligero, modesto, pobre, joven, leve, menor, escaso, minúsculo, raquítico, corto, diminuto, breve, and meñique (to translate little finger). And only in a small number of times the quantifier poco has been used to translate little followed by a count noun; it usually precedes non-count nouns. 
Apart from the lexeme pequeño/a/os/as, diminutives appear to be an important resource in Spanish to express the meaning conveyed by the English item little.

\section{DISCUSSION AND PEDAGOGICAL IMPLICATIONS}

The use of direct or data-driven application of corpora with adult learners has lately been encouraged, especially at university level (Granath, 2009; Oksefjell-Ebeling, 2009), because grown-up students learn better if consciousness-raising activities, reflection and inferencing work are incorporated into the teaching process. However, graded and carefully selected exposure to particular language items by means of meaningful, content-based tasks and opportunities for communicative practice are much better suited for YL. That is the reason why indirect applications of corpora can be more useful for YL's needs in helping teachers and material designers focus on key words and their collocational patterns to prepare adequate syllabi. The corpus-based analysis of little presented above has revealed the following facts, which can be used as a source of information for curriculum planning in the context of ELT to Spanish YL:

○ In descending order of frequency, little occurs in different types of corpora as follows: children's short stories (3,794.54 pmw), fiction (1,710.12 pmw), general language including both fiction, non-fiction, newspaper articles, magazine articles and miscellanea (893.57 pmw) and non-fiction (584.13 pmw) (see Tables 2, 3 and 4). This means that it is an important word in children-oriented texts, like stories, as compared with other domains, and it is particularly less common in more serious, fact-based, adult-oriented genres.

- The most common pattern of little in children's short stories is 'little + NP', whose head is a count noun (typically related with people, family relationships, fantastic creatures, animals, places and parts of the body) and is sometimes premodified by colour, material, age or size adjectives or postmodified by diminutives: e.g. little boy, little red hen, little glass slippers, little old woman, little weeny dwarf, little ducklings. This pattern accounts for almost $78 \%$ of the occurrences of little in CSS. In contrast, it is much less frequent in non-fiction (19\%), where the prevailing use is this pattern but with a non-count noun (36\% of the cases). If we consider the pattern as a whole, regardless of the use of count, non-count or proper nouns, it accounts for slightly more than $90 \%$ in CSS as compared with slightly more than $56 \%$ in non-fiction. The profile of the use of little in non-fiction is characterized by a greater distribution of patterns with more similar percentages, which reflects more complexity. Another difference in the use of this pattern across corpora is the positive connotations associated with the head nouns in these NPs in CSS (e.g. poor little thing, sweet little girl) in comparison with more negative associations found in the P-ACTRES fictional subcorpus (e.g. little fool, little bastards).

- As for the common translations into Spanish, these include, above all, the lexeme pequeño/a/os/as closely followed by diminutives, as well as some assorted translation 
solutions like modulation, transposition, idiomatic expressions, omission, etc. These two main translations along with the scarce use of the quantifier poco also pinpoint the prevalence of the use of little in NPs with count nouns in fiction.

These corpus-based findings might be incorporated into a syllabus in ELT to Spanish YL, following the what-to-teach and when-to-teach questions in the lexical approach. As for the how-to-teach-it, story-telling, task-based and communicative methodologies, which focus on meaningful learning and the usefulness of exposure and interaction in the classroom are highly suitable. Therefore, first, we can grade and select the input and itemize the language syllabus, following the main aim of the lexical approach: to "specify words, their meanings, and the common phrases in which they are used" (Willis, 1990: 15), that is, to focus on the behavior of words and their syntagmatic relationships and then we can devise tasks where these pre-planned language items are embedded.

The following ideas illustrate how to make use of some information inferred from the previous corpus-based study (examples extracted from the CSS corpus). The main tasks can be based on story-telling activities (well suited for auditory learners) supported by contextual support such as gestures and movements (ideal for kinesthetic learners) and visual materials like big books, flashcards, pictures, puppets or realia (very useful for visual learners). Storytelling-based activities can easily cater for all learning styles and they have been extensively used in FLT to YL over the last few decades (Chou, 2014; Slattery \& Willis, 2001). It is good to combine extensive reading and/or listening, through story-telling/reading, that is, input instruction, with specific activities that draw attention to some particular lexical items in the story (e.g. little), that is, with word-focused instruction, because, "the truth is probably in the middle: while a certain amount of extensive reading is certainly possible and useful, some word focused tasks can also be quite effective" (Laufer, 2016: 6).

What this article suggests as a prospective application of the corpus-based findings is the adaptation of stories to be used in the classroom in two different and apparently contradictory ways, i.e. a) simplifying the story - "simplifying input (e.g. by lowering the speech rate and modifying input) aids comprehension" (Ellis, 2008: 247) and b) adding to the story. Simplification can be achieved by changing certain complex grammatical structures into some easier patterns and by reducing the type-token ratio -repetition of items facilitates comprehension and also creates lexical cohesion instead of using synonyms, which make the text richer but more difficult. On the other hand, we should adapt the stories by including more instances of the lexical item which is the core of the lesson, in this case, the word little, for instance adding 'the little one', 'little by little', a verb + 'a little' (e.g. 'chat a little'), 'a little + AP' (e.g. 'a little louder/ longer/ less rough') and so on in suitable places in the story without altering the ultimate meaning or any important parts of the story. 
The teacher can also use visual support materials like flashcards about characters or objects that will later appear in the story and describe them using NPs with intensifiers, e.g. 'very little child', 'so little food', several premodifiers, including colour adjectives, e.g. 'a little pink rose', 'a little white cat', material, e.g. 'her little glass slippers', 'a precious little golden bird', age, e.g. 'the little old woman', size, e.g. 'a little weeny dwarf', 'a tiny little cottage', origin, e.g. 'the little country mouse', opinion, e.g. 'pretty little beds', 'sweet little girl', 'cute little hat', 'beautiful little dog', 'poor little mermaid', etc.

Other input-based activities can be carried out (e.g. memory games, bingo, Total Physical Response and listen-and-do activities) to get the learners familiar with different meanings and uses of the word little:

○ Meanings related to quantity, size, extent, duration, age, positive connotations, etc.

- Grammatical uses as a determiner, pronoun, adjective and adverb.

- Phraseological uses in different collocations, idioms and fixed expressions.

- In particular, some chunks of language can be especially taught to YL. In this case, the chunks can be NPs that include salient lexical items, like the nouns and adjectives found to collocate with little in this study, and grammatical features, like the order of adjectives and regular and irregular plurals (e.g. little mice and little children).

Finally, raising awareness of some contrastive differences between the L1 and the L2 can lead to better understanding of the changes needed in the transfer. In this case the tendency for premodification in English (the use of little preceding count nouns) versus the frequent use of suffixes in Spanish to express small size is a difference worth noticing and showing to learners at some particular point.

\section{CONCLUSIONS}

What has been suggested in this paper is that the lexical item little has earned its own right to be included as one of the first and most important words to be taught to YL of English. It has been argued that a lexical syllabus based on corpus findings is a good way of selecting, sorting and grading the contents to be taught, especially focusing on particularly interesting items both in terms of frequency and learners' needs. By revolving around key words like little, working on them in meaningful contexts and emphasizing their most relevant uses and patterns (especially those that are significantly more frequent in children-oriented texts such as children's short stories), the learning of these key words can be facilitated.

The word little has been found to be particularly frequent in the genre of children's short stories, confirming previous findings, for example Biber et al. (1999), who claimed that little tends to occur more often in spoken and informal discourse and in narrative texts, than in formal writing (section 2). Consequently, we can assume that this word is likely to be 
common in all other types of communication addressed to or produced by children, like carer talk, children's TV shows, children's conversations, etc. but proving this hypothesis would require further research.

The choice of key vocabulary for syllabus inclusion can be justified on the grounds of applied corpus linguistic research and it can be further complemented through translation and contrastive studies. Finally, an indirect application of the corpus-based findings has been advocated with the suggestion of teaching methods for YL based on story-based communicative approaches, where the stories are adapted to the teaching purposes and the lexical items are put to use in context both in comprehension and production activities.

\section{ACKNOWLEDGEMENTS}

This paper has been financially supported by project FFI2016-75672-R (Spanish Ministry of Economy and Competitiveness).

\section{REFERENCES}

Biber, D., Johansson, S., Leech, G., Conrad, S. \& Finegan, E. (1999). Longman Grammar of Spoken and Written English. London: Longman.

Carter, R. \& McCarthy, M. (2006). Cambridge Grammar of English. Cambridge: Cambridge University Press.

Chou, M. (2014). Assessing English vocabulary and enhancing young English as a Foreign Language (EFL) learners' motivation through games, songs, and stories. Education, 3-13 42(3), 284-297.

Ellis, R. (2008). The Study of Second Language Acquisition. (2nd ed.). Oxford: Oxford University Press.

Evert, S. \& Hardie, A. (2011). Twenty-first century Corpus Workbench: Updating a query architecture for the new millennium. In Proceedings of the Corpus Linguistics 2011 conference, Birmingham: University of Birmingham. Retrieved May 14, 2018 from https://www.birmingham.ac.uk/research/activity/corpus/publications/conferencearchives/2011-birmingham.aspx.

Flowerdew, L. (2015). Corpus-based Research and Pedagogy in EAP: From Lexis to Genre. Language Teaching, 48(1), 99-116.

Granath, S. (2009). Who benefits from learning how to use corpora? In K. Aijmer (Ed.), Corpora and Language Teaching (pp. 47-65). Amsterdam: John Benjamins.

Hofland, K., \& Reigem, Ø. Translation Corpus Aligner, version 2.

Kilgarriff, A., Baisa V., Bušta J., Jakubíček M., Kovář V., Michelfeit J., Rychlý P. \& Suchomel, V. (2014). The Sketch Engine: ten years on. Lexicography, 1(1), 7-36. 
Laufer, B. (2016). From word parts to full texts: Searching for effective methods of vocabulary learning. Language Teaching Research, 21(1), 5-11.

Lewis, M. (1993). The Lexical Approach. Hove: Language Teaching Publications.

McCarthy, M. \& Handford, M. (2004). "Invisible to us?": A preliminary corpus-based study of spoken business English. In U. Connor \& T. A. Upton (Eds.), Discourse in the Professions. Perspectives from Corpus Linguistics (pp. 167-201). Amsterdam: John Benjamins.

Molina, L. \& Hurtado, A. (2002). Translation Techniques Revisited: A Dynamic and Functionalist Approach. Meta 47(4), 498-512.

Nation, I.S.P. (2001). Learning Vocabulary in another Language. Cambridge: Cambridge University Press.

Nattinger, J. \& DeCarrico, J. (1992). Lexical Phrases and Language Teaching. Oxford: Oxford University Press.

Norlund, M. (2016). EFL textbooks for young learners: a comparative analysis of vocabulary. Education Inquiry 7(1), 47-68.

O'Keeffe, A., McCarthy, M. \& Carter, R. (2007). From Corpus to Classroom. Language Use and Language Teaching. Cambridge: Cambridge University Press.

Oksefjell-Ebeling, S. (2009). Oslo Interactive English: Corpus-driven exercises on the Web. In K. Aijmer (Ed.). Corpora and Language Teaching (pp. 67-82). Amsterdam: John Benjamins.

Pym, A. (2016). Translation solutions for many languages: Histories of a flawed dream. London: Bloomsbury.

Roig-Marin, A. (2017). Why should we care about sound symbolism in EFL learning?: Two pilot studies. IJES, 17(1), 17-36.

Römer, U. (2010). Using general and specialized corpora in English Language Teaching: Past, present, future. In M. C. Campoy-Cubillo, B. Bellés-Fortuño \& M. L. Gea-Valor (Eds.), Corpus-based approaches to English Language Teaching (pp. 18-35). London: Continuum.

Sapir, E. (1929). A study in Phonetic Symbolism. Journal of Experimental Psychology, 12, 225-239.

Schmid, H. (1994). Probabilistic Part-of-Speech Tagging Using Decision Trees. In Proceedings of International Conference on New Methods in Language Processing, Manchester, UK. Retrieved May 14, 2018 from http://www.cis.uni-muenchen.de/ schmid/tools/TreeTagger/.

Shinohara, K. \& Kawahara, S. (2010). A cross-linguistic study of sound symbolism: the images of size In N. Rolle, J. Steffman \& J. Sylak-Glassman (Eds). Proceedings of the Thirty Sixth Annual Meeting of the Berkeley Linguistics Society (pp. 396-410). Berkeley, CA: Berkeley Linguistics Society.

Sinclair, J. \& Renouf, A. (1988). A lexical syllabus for language learning. In R. Carter \& M. McCarthy (Eds.), Vocabulary and Language Teaching (pp. 140-160). London: Longman.

Sinclair J. (1999). The lexical item. In E. Weigand (Ed.), Constrastive Lexical Semantics (pp. 1-24). Amsterdam: John Benjamins.

Siyanova-Chanturia, A. \& Webb, S. (2016). Teaching vocabulary in the EFL context. In W. A. Renandya \& H. P. Widodo (Eds.), English Language Teaching Today (pp. 227-239). Berlin: Springer.

Slattery, M. \& Willis. J. (2001). English for Primary Teachers. Oxford: Oxford University Press.

Stubbs, M. (1997). Whorf's children: critical comments on critical discourse analysis. In A. Wray \& A. Ryan (Eds.), Evolving Models of Language (pp. 100-16). Clevedon: Multilingual Matters.

(c) Servicio de Publicaciones. Universidad de Murcia. All rights reserved. IJES, vol. 19(1), 2019, pp. 1-20 Print ISSN: 1578-7044; Online ISSN: 1989-6131 
Ultan, R. (1978). Size-Sound Symbolism. In J. Greenberg (Ed.), Universals of Human Language II: Phonology (pp. 525-568). Stanford: Stanford University Press.

Willis, D. (1990). The Lexical Syllabus. London: Collins. 